\title{
The Impact of Civil Society on Control of Corruption: A Comparative Study of Russia and Iran
}

\author{
Amir H. Estebari", Carleton University
}

\begin{abstract}
This paper studies the role of civil society in controlling corruption in public services in two developing countries: Russia and Iran. Research on the relationship between civil society and corruption control in these two countries is insufficient. Selecting Russia and Iran for comparison is based on similarities between them in terms of economic and political systems, and the developments of their civil societies. This paper compares the historical developments and the status of corruption and civil society in both countries; the efforts that civil society actors have made in battling corruption; and the state's reaction to these attempts. This study covers a period of almost three decades from the collapse of the Soviet Union in 1991 to 2020. The
\end{abstract}

\footnotetext{
*Biography :
}

Amir Estebari is a recent graduate of the Norman Paterson School of International Affairs at Carleton University and holds a master's degree in international affairs with a specialization in international economic policy. Born and raised in Iran, he has been involved in civic activism and business in the country for several years. He has a background in research and analysis focused on Eastern Europe and the Middle East. His main research interests are global political economy, transition economies, development, and the interaction between the state and civil society in developing countries.

\section{Biographie :}

Amir Estebari est récemment diplômé de la Norman Paterson School of International Affairs de l'University Carleton et détient une maîtrise en affaires internationales avec une spécialisation en politique économique internationale. Originaire de l'Iran, il est impliqué en affaires et continue un engagement communautaire dans le pays. II se spécialise en recherche et en analyse axé sur l'Europe de l'Est ainsi que le Moyen-Orient. Ses intérêts principaux sont la politique économique globale, les économies de transition, le développement, et l'interaction entre l'État et la société civile dans les pays en voie de développement. 
findings of the study show that the civil societies in both countries have had limited impact on controlling corruption over the period. Although these findings do not support a prominent role for civil society in control of corruption in past, the author argues that, according to some evidence, there is a possibility of a stronger role for civil society in combatting corruption in both countries in the future.

Keywords: Civil society, control of corruption, rentierism, hybrid regimes, Russia, Iran

\section{Résumé}

Ce document étudie le rôle de la société civile dans le contrôle de la corruption dans les services publics dans deux pays en développement: la Russie et l'Iran. Les recherches sur la relation entre la société civile et le contrôle de la corruption dans ces deux pays sont insuffisantes. Le choix de la Russie et de l'Iran à des fins de comparaison repose sur leurs similitudes en termes de systèmes économiques et politiques, ainsi que sur les développements de leurs sociétés civiles. Ce document compare les développements historiques et le statut de la corruption et de la société civile dans ces deux pays ; les efforts déployés par les acteurs de la société civile pour lutter contre la corruption; et la réaction de l'État à ces tentatives. Cette étude couvre une période de près de trois décennies allant de l'effondrement de l'Union soviétique en 1991 à 2020. Les résultats de l'étude montrent que les sociétés civiles de ces deux pays ont eu un impact limité sur le contrôle de la corruption au cours de cette période. Bien que ces résultats ne soutiennent pas un rôle proéminent de la société civile dans le contrôle de la corruption dans le passé, l'auteur soutient que, selon certaines preuves, il est possible que la société civile joue un rôle plus important dans la lutte contre la corruption dans les deux pays à l'avenir.

Mots clés: Société civile, contrôle de la corruption, rentierisme, régimes hybrides, Russie, Iran. 


\section{Introduction}

We find corruption everywhere, but it is more pervasive in countries with lower accountability of the state. This paper studies and compares the role that civil society plays in making the state accountable for controlling corruption in two developing countries, Russia and Iran, over almost three decades from the collapse of the Soviet Union in 1991 until 2020. Despite some criticisms (Gibelman \& Gelman 2004; Greenlee, Fischer, Gordon \& Keating 2007), scholars have written widely about the role of civil society in controlling corruption (Villanueva 2020, 553 - 554). Civil society not only raises awareness about corruption in public institutions, but it monitors the performance of these institutions and officials. It reports on any corrupt activities and organizes people to push the state for more transparency and accountability (Tusalem 2007; Mungiu-Pippidi 2013; Grimes 2013). Russia and Iran are not an exception in this regard. There are four reasons for choosing these two countries for comparison in this paper:

\section{Economic Dependency on Natural Resources}

Both Russia and Iran have economies that are heavily dependent on the export of natural resources, mainly oil. This dependency, according to numerous explanatory, statistical and case studies, would encourage rent-seeking political behaviour among officials (Auty 2001; Karl 2004); deviate the economy from more productive activities and hinder development (Karl 2005; Gylfason \& Zoega 2006; Arezki, Nabli \& IMF 2012; Badeeb, Lean \& Clark 2017); liberate the state from reliance on taxes, leading to unaccountability and inefficiency of the public sector (Karl 2005; Dunning 2008; Auty 2010); help the state to adopt less democratic policies (Dunning 2008; Aslaksen, S. 2010; Arezki \& Brückner 2011; Ross 2013); and would raise fraud in the political and economic systems (Arezki \& Brückner 2011; Arezki \& Gylfason 2013; Okada \& Samreth 2017). The share of mineral exports out of total exports in Russia were 42, 51, 63, 56, and $61 \%$ in 1992, 1997, 2007, 2017, and 2018, respectively (OEC n.d. a). The share of minerals in Iran is higher and less diversified, accounting 
for over $92,87,88,80$, and $78 \%$ of total exports in 1987, 1997, 2007, 2017, and 2018, respectively (OEC n.d. b). For a long time, scholars have identified Iran as a 'rentier state' but avoid attributing this to Russia due to its more diversified economy (e.g., Tompson 2005).

However, the Russian economy has been showing signs of rentierism recently. According to Herb $(2005,298)$, 'rentierism' is measured by the percentage of rents in government revenues, whereas 'natural resource dependency' is measured by the share of natural resources exports as a percentage of GDP. In Russia, the share of oil and gas revenues in the total federal budget revenues was $46.3 \%$ in 2018, which is 6.7 percentage points more than this in 2017 (Accounts Chamber of the Russian Federation 2019). The Russian state has recently increased its control over the Russian hydrocarbon resources and industry by owning more shares in giant oil and gas firms such as Rosneft and Gazprom, as well as the monopolization of transit pipelines through Transneft, which is a national company, without renationalizing the industry (Locatelli 2006; Gulf Oil \& Gas n.d.). All oil and gas reserves in Iran are owned and produced by Iran's National Oil Company.

\section{Hybrid Political Regimes}

Russia and Iran feature "hybrid" political systems which combine both democratic and authoritarian features. The combination of authoritarian elements in a political system with rentierism or dependency on natural resources could result in high degrees of corruption, low accountability of the state, and weakness of the civil society. Rents also encourage 'statism', which is an additional obstacle to the development of civil society and makes citizens more vulnerable to corrupt exploitation (Aytaç 2016, 77; Johnston 1998, 88). Levitsky and Way call Russia a "competitive authoritarian" state, where meaningful democratic institutions create some channels through which opposition forces could confront the ruling elite (Levitsky \& Way 2002). They believe Iran is governed by a "tutelary regime", where elections are competitive, but the power of elected governments is limited by nonelected religious and military authorities 
(Levitsky \& Way 2010, 14). Iran's legislative election in 2020 has made observers pessimistic about the competitiveness of the elections in the future. The Economist Intelligence Unit's Democracy Index does not follow Levitsky \& Way's classification, but it shows that democracy in both countries has deteriorated over the last fourteen years (EIU 2020).

\section{The Use of Checks and Balances}

The political system in both countries makes use of checks and balances to control corruption. For instance, the Russian president needs the consent of parliament for passing legislations, while the two chambers of the Federal Assembly (State Duma and the Federation Council) can override a presidential veto. Additionally, the Federation Council must approve all presidential appointments to the Supreme Court and the Constitutional Court (Remington 2009, 42; Encyclopedia Britannica n.d.). The recent amendments to the Russian Federation Constitution in 2020 have expanded the parliament's role in government formation and given more power to the Federation Council in the selection or dismissal of the highest judges. However, some scholars argue that since the members of the Council are directly or indirectly nominated by the president, and some amendments have increased the president's power, the whole system that separates powers will depend only on the president (Shashkova, Verlaine \& Kudryashova 2020; Hines, Josefson, Strizh \& Marchenko 2020; Laruelle 2020). Iran also has its system of checks and balances. In comparison to Russia, the legislature in Iran has more control over the executive power. The parliament (Majlis) should confirm presidential appointments as ministers. Majlis can question and impeach the ministers, the whole cabinet, and even the president who is directly elected by the citizens as the head of the executive power. Passing a bill also needs affirmation by both Majlis and the Guardian Council. Moreover, the president of Iran has zero control over the judicial power (Buchta 2000). 


\section{Development of Civil Society}

The fourth and last similarity between the two countries is the resemblance in the development of civil society in both and in the way their states confront civil activism. This analogy will be discussed later in the "Research Findings" section, where the critical developments of civil society and the state's response to anti-corruption activism in both countries are explained and compared.

\section{Corruption and Civil Society}

Johnston $(1998,89)$ defines corruption as the "abuse of public roles or resources for private benefit." 'Systemic corruption' happens when major institutions and processes of the state are routinely dominated by corrupt individuals and groups, and people have few practical alternatives to dealing with corrupt officials. Shim and Eom (2009) identify three approaches to fighting systemic corruption: administrative reform, law enforcement, and social change (social capital). The first two are implemented at the state level and the third is at the social level. Citizens' participation in anti-corruption movements through a cultivated civil society is a deterrent to corruption because it not only changes cultural attitudes from accepting corruption to avoiding it, but also increases the bottom-up accountability pressure on the state. Civil society can identify corruption within the legal and administrative system, participate in decision makings to enhance transparency, and raise public awareness.

The definition of civil society has changed over the history of political thought. Kaldor $(2003,10)$ finds the common core of meaning among these definitions as "a rule-governed society based on the consent of individuals". In general, civil society refers to space for collective action around shared interests, purposes, and values in the 'third sector' of society, which is distinct from government and business actors. Civil society includes charities, non-governmental organizations (NGOs), community groups, women's organizations, 
religious organizations, professional associations, trade unions, social movements, and advocacy groups.

\section{Methodology}

The main question of this paper is: "How significant is the impact of civil society on the control of corruption by the state in Russia and Iran?" The independent variable of this research is 'civil society', and the dependent variable is 'control of corruption by the state'. Each variable will be studied separately in each country. There are one null and two alternative hypotheses to be tested individually for each case:

H0: Civil society has had no impact on the state's control of corruption. H1: Civil society has had a limited impact on the state's control of corruption.

H2: Civil society has had a significant impact on the state's control of corruption.

To test the hypotheses, first, a short comparison of corruption levels between Russia and Iran will be provided, using data from economic estimates as well as the Corruption Perception Index (CPI), measured by the Transparency International. Then, the critical developments of civil society and corruption in both countries, from 1991 to the present, will be discussed and compared. This comparison is provided through a historical lens and a quantitative comparison of civil society robustness based on the Core Civil Society Index (CCSI), measured by the Varieties of Democracy Institution. Afterwards, the efforts that civil society actors have made in battling corruption and the state's reaction to these attempts in both countries will be compared, using historical evidence. Then, the probability of civil society's success in reducing corruption will be analyzed by comparing the Control of Corruption Value (CCV), introduced by the World Bank, with the CCSI in Russia and Iran over the period. Ultimately, a conclusion about the hypotheses of the paper will be offered based on the proposed quantitative comparisons and the historical evidence. This section will also include an analysis on the potential capacity of anticorruption activism in both societies. 


\section{Corruption in the Public Sector}

Transparency International publishes the Corruption Perceptions Index (CPI) annually. It scores and ranks countries/territories based on various data sources which capture the assessment of experts and business executives on corrupt behaviours in the public sector, such as bribery, diversion of public funds, nepotism, etc. as well as the mechanisms available to prevent corruption in a country, such as prosecution of corrupt officials, laws on financial disclosure, conflict of interest prevention, etc. (Transparency International n.d. b). Russia took the CPI rank of 76 out of 85,86 out of $133,147,138$, and 129 out of 180 countries in the world in 1998, 2003, 2008, 2018, and 2020, respectively (Transparency International n.d. a). However, Iran is not in a better situation. It was ranked 79 out of 133, 141,138, and 149 out of 180 countries in 2003, 2008, 2018, and 2020, respectively (Transparency International n.d. a). In the Index, no data is provided for Russia and Iran prior to 1998 and 2003, respectively. However, in a separate study, Sadeghi, Arani, and Shahri (2011) estimate that corruption in Iran had an upward trend from 1988 to 1999. More accurate assessments are accessible about the level of corruption in Russia. Businesses in Russia were estimated to pay over US $\$ 300$ billion in bribes each year (Sullivan 2006, 34). Criminal groups in oil, gas, and rare metals industries spent up to $50 \%$ of their revenues on bribing officials at various levels. Some $10 \%$ of total revenues in small- and middle-size businesses were taken by corruption (Levin 2000, 114 115).

\section{Critical Developments of Civil Society and Corruption in Russia}

Before the October Revolution in 1917, Russian civil society was mainly comprised of religious organizations such as the Russian Orthodox Church. After the Revolution, the Church property was nationalized, and religious teaching and publication became illegal (Shelley 2005, 3; Evans 2006, 31). Bolsheviks supported voluntary organizations in the early years of the Soviet Union. However, in the first half of the 1930s, self-governing voluntary organizations including 
trade unions were replaced by a few centralized quasi-nongovernmental organizations (NGOs) established from above such as the Communist Union of the Youth, the All-Union Society of the Deaf, and Society for the Protection of Nature (Romanov \& larskaiaSmirnova 2015, 360). Arato $(1991,199)$ and Uhlin (2006, 38 - 39) believe that a civil society existed in those years up until Joseph Stalin (1927 - 1953) began to demolish it. After him, only some of the basics of civil society were rebuilt at a very low level. The redevelopment of civil society took place when Mikhail Gorbachev introduced two government policies, Perestroika (1985) and Glasnost (1988), with the aims of "socialist pluralism", openness, and transparency. Independent associations and unions began to emerge, representing various groups such as the disabled, pensioners, veterans, journalists, mine workers, women, and environmentalists (Shelley 2005, 7; Uhlin 2006 , 39). By 1987, more than 30,000 informal groups independent from the Communist Party had formed, growing to 60,000 in 1989 (Weigle 2000, 79 - 80). Furthermore, in 1986 and 1988, the USSR Law on Individual Labour Activity and the USSR Law on Cooperatives allowed private enterprises to be formed for the first time (Blasi, Kroumova \& Kruse 2018). Gorbachev started to turn the state enterprises into joint-stock companies with shares offered in stock exchanges in 1990 (Hertzfeld 1991).

In December 1991, the Soviet Union collapsed and there were around 45,000 state enterprises to be privatized under Boris Yelstin's presidency (Sachs 1992, 46). Privatization of state properties and the weakness of the central state offered unprecedented opportunities to organized crime groups to intensely penetrate the state structures at the local, regional, and national levels (Volkov 2016; Stephenson 2017). Privatization facilitated 'crony capitalism' and the transfer of significant wealth to a relatively small group of business oligarchs, particularly natural gas and oil executives. The culture of corruption also began to prevail over the culture of civil society (Shelley 2005, 18).

In a different movement in 2004, Vladimir Putin's government started to gain control of some giant privatized extractive enterprises 
by increasing its stake in these companies (Hanson 2007, 877). Towards civil society, Putin had a "dual strategy" of raising restrictions on NGOs that were independent of public funding or funded by international donors, while financially supporting pro-Kremlin philanthropic institutions as the competitors of the first two groups (Romanov \& larskaia-Smirnova 2015, 361). For more control on civil society, in January 2006, parliament passed a law that gave extensive new powers to the Government to monitor activities of NGOs and suspend them if they pose an alleged threat to national security (Henderson 2011, 20; Romanov \& larskaia-Smirnova 2015, 361). Based on the new regulations, hundreds of NGOs were closed, although many of them were already inactive (Gnezdilova 2009). Ninety percent of human rights institutions were deprived of receiving grants and exemptions from taxes (Romanov \& larskaia-Smirnova 2015,361 ). Additionally, governmentally organized NGOs (GONGOs) - e.g., Nashi - began to emerge. Even Dmitry Medvedev's more liberal stance $(2008-2012)$ did not ease the situation for independent NGOs (Romanov \& larskaia-Smirnova 2015, 362). In July 2012, after Putin returned to the presidency, a new law required the NGOs receiving funds from abroad to be classified as "foreign agents", which echoed Stalin-era denunciation of alleged anti-Soviet spies (BBC 2015; BBC 2019). The definition of 'treason' was also amended to include the provision of consultative or assistance to foreign states, international or foreign organizations, or their representatives in activities against national security. According to this law, 76 organizations were declared foreign agents (Khodorkovsky 2018).

There are three types of civil society NGOs and associations in Russia: (1) those who receive financial and operational support from the state, as GONGOs; (2) those who receive funds from foreign and international institutions like the World Bank, European Bank of Reconstruction, Ford Foundation, Soros Foundation, etc. (Olimpieva 2009, 212); and (3) the smallest number of NGOs, who are independent of the state or foreign aids.

Monitoring civil society institutions and keeping them dependent on public resources are the main two tools that the Kremlin 
uses to control these institutions. Moreover, many civil activists and journalists have been arrested, kidnapped, or murdered after 2000. Overall, the situation for civil society has deteriorated in Russia after Yelstin (Holmes 2012, 247). A survey by the European Bank for Reconstruction and Development in 2010 revealed that Russia had the second-fewest number of active or passive members of civil society associations among 34 nations (Beissinger 2017).

\section{Critical Developments of Civil Society and Corruption in Iran}

Like Russia, Iranian civil society has experienced ups and downs throughout history. The roots of civil society in Iran dates back to Iran's Constitutional Revolution (1905 - 1911) when a variety of civic and political associations (Anjomans) emerged to force the Qajar absolute monarchy to accept the establishment of a national judiciary system and a parliament. The top-down modernization efforts under the reign of Reza Pahlavi (1925 - 1941) gradually turned the mass of Iranians into 'citizens' despite the blatant violation of political freedoms in this period (Gheissari \& Nasr 2009). His son and successor, Mohammad Reza Pahlavi, gave more freedom to civil society up until the coup d'état in 1953. Since then, only state-sponsored political groups, associations, and NGOs have been active, while those who opposed the system were prosecuted (Abrahamian 2018). Revolution 1979 opened the space for civil activists for only about two years, and then the freedom of civil activities became even more restricted than in the past.

The Revolution allowed the state to take control of previously private enterprises (including 37 banks and 10 insurance companies), and to create Revolutionary Foundations, which are important business holdings representing the Iranian version of state capitalism (Azad 2010, 62, 66). These foundations do not pay any taxes to the government and are only accountable to the Supreme Leader of Iran. An official report declares that 19 out of 37 Revolutionary Foundations do not provide any data about their economic activities (Sazandegi 2019). The first privatization movement in the Islamic Republic took place under the presidency of Akbar Hashemi Rafsanjani (1989 - 
1997), who transferred the ownership of around 800 state-owned enterprises to the private sector (Azad 2010, 64). Also, the significant decline in the oil revenues from 1993 to 1998 made the state more dependent on taxes, giving leverage to business associations and trade unions to press the government for their demands (Haj Yousefi 1998). Mohammad Khatami's government (1997 - 2005) gave high levels of freedom to civil society, which was unprecedented after Revolution. However, this policy was counteracted by his opponents in other branches of power. For example, following the adoption of the new press law in the parliament where the government opponents had the majority, the judiciary power shut down 16 reformist newspapers in April 2000 (BBC 2019). When Mahmoud Ahmadinejad came to the office in 2005, corruption surged and gradually became systemic, and his government oppressed civil society severely. In early 2006 , the law on civil organizations was changed, restricting the legal space of action for civil agents. In the law, the term NGO was changed to Sazmanhaye Mardom Nahad (SAMAN), normally translated as 'People's Organizations'. At the theoretical level, 'SAMAN' was meaningless. It removed the boundary between NGOs as players in the third sector of society and the state (Rivetti 2012, 287 - 289).

In Iran, the legal system is preventive for NGOs, requiring permission before action (Volunteer Activities 2018, 6). Being arrested, kidnapped, or even murdered is common among civil activists in Iran. There are mainly three groups of NGOs in the country: (1) the state-sponsored NGOs, which receive considerable funds from public sources; (2) the independent ones, which financially rely on private sources; and (3) those that are in-exile, with offices in western countries and no offices inside Iran, receiving their funds from foreign and international institutions. None of the NGOs inside the country can receive funds from other countries since they would be regarded as spies. Online and virtual social networks are very important assets for Iranian civil society (Volunteer Activities 2018, 6).

Both states, in Russia and Iran, apparently utilize civil society as a domination tool along with other suppressive measures to legitimize their policies and plans (Stewart \& Dollbaum 2017; Squier 
2002; Volunteer Activities 2018). For both countries, Figure 1 illustrates the trends of the Core Civil Society Index (CCSI), presented by Varieties of Democracy Institution, as a measure of the robustness of civil society (V-Dem n.d.). Levels of state repression, entry/exit control, and citizen activism are the main components of this index (Bernhard 2015, 9). As can be seen, Russian civil society had its maximum strength with 0.69 points on average from 1992 to 1999. Since then, this point steadily went down to 0.28 in 2017 . The timeline for Iran shows a different trend. The civil society began improving in 1988, with another jump in 1996 to reach a peak and a plateau of 0.51 points until 2004. Then it started to plunge sharply to hit a score as low as 0.2 points in 2006 . Although the situation improved between 2013 and 2016, the Index hit the trough at 0.13 in 2019. Civil societies in both countries have experienced limited periods of recovery and expansion. However, the overall trend for both has been remarkably downward since 2004-2005.

Figure 1: Core Civil Society Index for Russia and Iran (1988 - 2019)

\section{Core Civil Society Index}

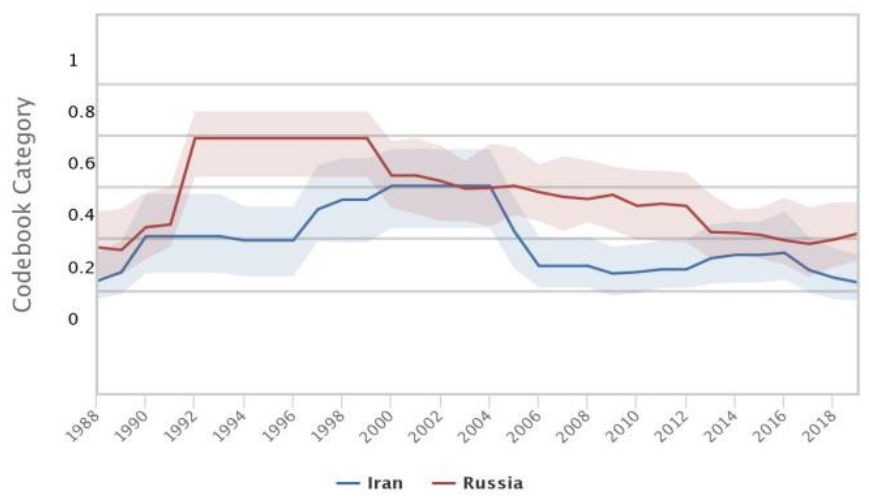

Source: Varieties of Democracy - www.v-dem.net 


\section{Comparison of Anti-Corruption Activism: The Case of Russia}

There is some evidence of anticorruption activism by civil agents in Russia. Olimpieva $(2009,211)$ suggests a categorization of NGOs that combat corruption in the public sector. On the one hand, 'ideological' NGOs, such as human rights organizations, seek the removal of corruption, transparent governance, and strengthening civil society. On the other hand, other civil agents such as business associations could be regarded as 'rational' NGOs who are against corruption because it impedes their interests and business development. Olimpieva also divides 'anticorruption initiatives' in a country into three categories: (1) 'bottom-up' initiatives, referring to the pressure coming from the civil society and imposed on the state; (2) 'top-down' initiatives, which take place through authoritative structures; (3) 'lateral' initiatives, which are implemented by international organizations. In Russia, since businessmen find informal or semi-informal intermediaries more effective than civic ways in solving the problems created by formal rules and institutional environment, 'rational' agents leave the problem of corruption to the state although it fails to demonstrate any coherent top-down anticorruption policy (Olimpieva 2009, 217; Shelley 2005, 12).

At the national level, some NGOs such as Open Russia Foundation, Centre for Anti-Corruption Research and Initiative (Transparency International Russia; CACRI/TIR), Terrorism, Transnational Crime and Corruption Center (TraCCC), Carnegie Moscow Center, Information Science for Democracy Foundation (INDEM), and Centre for International Private Enterprise (CIPE) Russia play the dominant role in lateral or bottom-up anti-corruption initiatives (Holmes 2012, 247; Shelley 2005, 11). The activities of these NGOs are mainly centred around conducting surveys, doing research, publishing reports, holding conferences, inviting experts, supporting libraries, and raising social awareness.

But at the regional or local level, more influential anticorruption activism can be observed. The Committee of Soldiers' Mothers is an NGO established by poor mothers whose sons were 
sent as soldiers to Chechnya. With the assistance of human rights forces, they have been challenging corruption in the army by pressing claims against corrupted military officials who had deprived them and their families of their legally entitled benefits. This NGO, unlike many other women's organizations, does not receive any funds from foreign or international institutions (Shelley 2005, 11). Some human rights groups such as the Citizens Watch have recently focused on corruption at the local level in St. Petersburg. Moscow Helsinki Group has also allocated resources to addressing municipal corruption that impedes service delivery to citizens (Shelley 2005, 12).

Other examples are legal institutions and scholars at Moscow State University and St. Petersburg University who try to address corruption inside and outside higher education. The Law School of St. Petersburg University addresses corruption in the judicial system by review and analysis of court decisions and law cases in St. Petersburg region in their peer-reviewed quarterly. There could be difficulties in accessing law cases, but these efforts have made the judges hesitant to accept bribes by knowing that their decisions are being scrutinized (Shelley 2005, 12).

\section{Comparison of Anti-Corruption Activism: The Case of Iran}

There are some weak elements of anti-corruption activism in Iran. This is done through 'bottom-up' or 'lateral' initiatives by 'ideological' agents. The 'rational' agents do not play a key role in reducing corruption because of the straightforwardness of informal and semi-informal ways of overcoming administrative barriers, like Russia.

Anti-corruption activism is quite new in Iran. Currently, there are around 14 anti-corruption NGOs, but only some of them are truly active, such as Administrative Health and Anticorruption Center (AHAC) which belongs to Tehran Chamber of Commerce, Transparency for Iran (TFI), Transparency and Justice Watch (TJW), Empowering Government and Society (EGS), Tadbir Institute of Economic Research (TIER), Organizational Behaviour Management 
Association (OBMA), and Administrative Health Center (AHC). Most of their activities are restricted to holding conferences and meetings, or publishing analyses and research. However, the TJW has taken more serious steps in combatting corruption. This NGO was established in September 2015 (TJW n.d.) by a group of conservative pro-state members of parliament. The head of the TJW is a member of the Expediency Discernment Council, which is one of the most important decision-making organs in the Islamic Republic. The political affiliations and connections of the TJW founders have secured them from limitations that authoritarian states usually impose on such organizations. The TJW has not only published the incidents of corruption among officials in the media, but it has brought some of these cases to trial. Some of the officials charged by the TJW in courts include the Vice President of Iran for disrupting the enforcement of a law requiring government managers to disclose their salaries (TJW 2019), the head of the Privatization Organization for patronage, the Ministry of Oil and its Minister for corruption and bribery, and two heads of the Central Bank for facilitating corruption in credit unions (Fars 2019). Moreover, the TJW asks people to report any incidents of bribery to this institution. Citizens can also submit petitions on the TJW website to send demands to government officials.

With regards to raising public awareness about corruption in Iran, international and exiled NGOs are more active. Transparency International has been measuring corruption in Iran since 2003. GAN Business Anti-Corruption Portal monitors and reports corruption in Iran, and offers free online training, and guidance on anti-corruption legislation. Article 19 teaches Iranians, in Farsi, about the "Law of Publication and Free Access to the Information" passed in parliament in 2008, to improve transparency in public services. The Pulse of Iran is a group that gives plenty of information, analyses, and training in Farsi to Iranian citizens on how to make politicians more accountable regarding corruption.

The State's Response to Anti-Corruption Activism 
The evidence reveals that, in both Russia and Iran, the state and the oligarchs' response to independent anti-corruption activism by civil agents are usually in the form of an iron fist. Individuals bear higher costs than civil society institutions in this case. In Russia, for example, Shelley $(2005,10-14)$ reports four cases of murder from 1998 to 2003 among the journalists who were investigating high-level and medium-level corruption. Justice for Journalists Foundation (JFJ 2019) also reports that from 2017 to 2019 , the number of attacks by the authorities and/or via legal and economic mechanisms doubled, exceeding 160 incidents. Arrests, detentions, criminal and civil prosecution, searches, questioning, and incarceration are the prevailing methods that the state uses against journalists (JFJ 2019). The anti-corruption campaigner Alexei Navalny has been arrested several times. He became a victim of suspected poisoning in August 2020, and he was sentenced to prison in February 2021. The former oligarch Mikhail Khodorkovsky, who had funded human rights and anti-corruption groups over $\$ 100$ million annually has been exiled (Shelley 2005, 5). For independent NGOs, Shelley (2005) reports on the creation of new administrative barriers for the re-registration of anti-corruption organizations.

The Yeltsin administration did not attempt to impede citizens' activism (Henderson 2011, 14 - 15). Nevertheless, Putin seems to prefer a "quasi-civil society", in which social organizations are subordinate to the authority of the state (Upadhyay 2006, 4651). His government splinters civil society into segments of those that are willing to cooperate with the state and those that are not. The former receive grants and other forms of support whereas the latter are intimidated and oppressed (Kolesnikov 2019a; Stewart \& Dollbaum 2017). This is an effort to imitate and mirror independent civil society by using its techniques and intercepting its terminology and initiatives (Kolesnikov 2019b). Putin has mentioned that "foreign-funded organizations do not follow people's interests" and has provided financial support to NGOs to counter Western assistance: \$15 million in 2006, $\$ 50$ million in 2007, and $\$ 70$ million in 2008 (Henderson 2011, 20). However, there are no institutional mechanisms for NGOs that 
receive these grants to influence the state for battling corruption (Olimpieva 2009, 213).

State response in Iran is not very different. Six media outlets were shut down or punished in September 2016 for reporting on corruption in Tehran Municipality. In connection to this case, one journalist, Yashar Soltani was arrested and charged with "publishing a confidential report" (GAN 2017; Dehghan 2016). Recently, Saba Azarpeik, a journalist who was active in revealing corruption by officials was arrested in January 2021 (DW Persian 2021). Journalist Fariborz Kalantari was declared convicted and sentenced to jail in February 2021 for revealing fraud by the First Vice-President's brother (Lipin \& Haghjoo 2021). Although Iranians have seen the murder of intellectuals, political opponents, and environmental activists, it has not happened to anti-corruption activists yet. NGOs face other problems. Rivetti (2012) reports new administrative impediments for registration or even cancellation of the permits already given to NGOs, after the presidency of Ahmadinejad in 2005. The Central Bank of Iran once sued the TJW, but the NGO was eventually acquitted (TJW 2018).

Rivetti (2012, 284 - 290) observes some trends of interaction between civil society and state in Iran, which are similar to such trends in Russia. She argues that both the reformist Khatami (1997 - 2005) and the hardliner Ahmadinejad (2005 - 2013) used techniques of "taming" civil organizations. Khatami provided funds to NGOs that were not truly independent. Their founders were mainly the political elite and supporters of the President. Ahmadinejad intimidated NGOs and President Hassan Rouhani (2013 - 2021) adopted almost the same policy. However, rather than shutting down civil society entirely, the regime has recently employed strategies to reassert state control over civil activism, getting closer to it and following a 'corporative model'.

It seems, in both Russia and Iran, that the state prefers having a subordinate civil society with no ability to confront the state. Therefore, civil organizations do not have the capacity to play a significant role in reducing corruption in public services. This can be 
understood by making a comparison between the trends of civil society development and control of corruption in each country. There is no data specifically about anti-corruption civil agents in these countries. The core civil society index (CCSI) is the only available and measurable data regarding the strength of civil society in both countries over time.

The World Bank has introduced an index for Control of Corruption on a scale of -2.5 to +2.5 , where the higher the index, the better the corruption controlled. The comparison between the CCSI trends illustrated in figure 1 with fluctuations of the Control of Corruption Value (CCV) in figure 2 does not indicate any relations between the development of civil society and corruption control in Russia and Iran. Figure 1 shows that Russia experienced an overall steady decline in the robustness of civil society from 1999 to 2019 but the control of corruption displayed substantial booms and busts over this period. In Iran, both the CCSI and CCV showed similar upward and downward trends during 1996 - 2002 and 2004 - 2010, respectively. However, the CCSI downward trend lasted until 2019 while the control of corruption started to rise in 2010 , followed by a sharp drop after 2014. Surprisingly, the fluctuations in the corruption control followed a similar trend in both countries until 2015. No data for the control of corruption in these two countries is available before 1996 (World Bank n.d.). 
Figure 2: Control of Corruption Value in Russia and Iran (1996 - 2019)

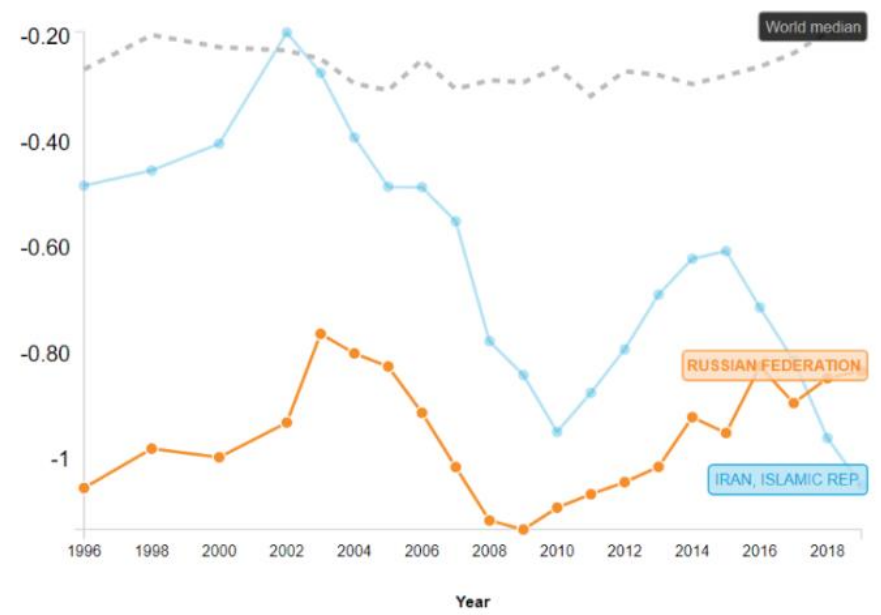

Source: World Bank - tcdata360.worldbank.org

\section{Conclusion}

There have been big anti-corruption protests in major and minor cities in Russia from March 2017 to spring 2018. Likewise, Iranian workers have been organizing sporadic but continual protests since 2017, and the country faced massive protests from December 2017 to January 2018 against economic hardship and corruption. Both societies have become more sensitive to prevalence of fraud and the way rents are distributed. Despite this increase in awareness, there are limited channels for anti-corruption NGOs in both Russia and Iran to influence the state. Publishing reports on corruption in the media, raising public awareness, taking legal actions in courts, and having unregular meetings with government officials are the tools that these NGOs are using to exert some influence on the state. Seemingly, NGOs could obtain better results from their anti-corruption efforts at the local level in Russia. The TJW in Iran could be an exceptional 
example of an NGO that is monitoring and reporting corruption at the national level seriously. They have been able to do it because they do not pass some red lines, such as inspecting Revolutionary Foundations that are indirectly governed by the Supreme Leader. In August 2020, the head of the TJW announced that he had asked the Supreme Leader to start transparency from his own Office. It seems that the Leader had welcomed the idea but then it was rejected by his Office (TJW 2020).

Apart from similarities of interaction between civil society and the state in both countries, the structure of power in the political system of each country could provide dissimilar opportunities for NGOs to keep the state accountable in combatting corruption. For example, as mentioned before, Iran's Majlis can impeach the cabinet ministers and even the president whereas Russia's Duma does not have this power. The Russian president can dissolve Duma whereas no one in Iran has the power to dissolve Majlis. These differences have led to more capacity of political competitions and conflicts within the system in Iran compared to Russia. Since many anti-corruption NGOs in Iran are founded by political elites, these NGOs have access to some channels to influence the behaviors and decisions in the political system, mainly through their personal connections. Anti-corruption activities could also be used as leverages by political elites to denounce and defeat their opponents. Opportunities for Russian NGOs are different. Henderson (2011), Ljubownikow, Crotty and Rodgers (2013) argue that the dependence of civil agents on the state is not the death of Russian civil society in Russia. Putin's administration has been trying to engage more social elites in government-affiliate organizations, which allows society to become more active in cooperating with the state but in a more supportive way rather than confrontational.

Overall, the evidence presented rejects the null and the second alternative hypotheses of this paper. Lack of association between trends of the CCSI and CCV over time rejects any significant impact of civil society on the state's control of corruption in both countries (the second alternative hypothesis). On the other hand, the existing evidence about the success of some civil organizations in 
controlling corruption in both countries rejects the null hypothesis. However, the first alternative hypothesis is not rejected and appears to be closer to reality in both countries. Therefore, the evidence gathered indicates that:

Civil society has had a limited impact on the state's control of corruption in both Russia and Iran (H1).

If this impact has been limited, are there any hopes for a more significant role of civil activists in battling corruption in the future? There are small signs that this could be so. Evidence in both countries shows that even the state-controlled NGOs and associations are important in the growth of civil society. State-sponsored civil organizations could join independent organizations to create a strong opposition against the state and put more pressure on it for better control of corruption. Rivetti (2012) argues that despite the efforts for structuring and intimidating civil activism, dynamics of independent advocacy have emerged in Iran, even among those NGOs with close connections to the state. Through a case study of the coalition between labour and student unions in Iran, Kalb (2019) suggests that the state-run and state-controlled associations remain important and could interact with the political system in novel ways. In authoritarian regimes, state-controlled 'corporatist' associations frequently co-exist alongside less state-controlled and more pluralist networks and associations. For obtaining more constituent partners, resources, and political opportunities, or for confronting external threats, organizations with limited resources might be tempted to enter into an alliance with each other or with more powerful actors. When corporatist associations decide to form coalitions with independent organizations, they become more likely to embrace broader, more inclusive, and more civil frames (Kalb 2019).

Chebankova $(2013,116$ - 117) presents the same argument by giving an example of state-sponsored organizations which have gradually deviated from supporting the state's policies. Boevoe Bratstvo is an organization of Afghan war veterans in Russia. Many of these veterans launched successful business careers during the 
1990s, helping them join the newly wealthy and middle class in the country. However, those who failed to achieve financial success resented the state for neglecting their social security needs and complained about the state's administrative inefficiency in dealing with their requests. Thus, the movement began to challenge the state by proposing military reform, which aimed at tackling corruption in the army and creating a more just, efficient, and transparent system of social security and legal enforcement agencies. Some of the leaders of the organization issued public statements criticizing the judicial and political system and advocating serious political change. Then, the movement began to co-operate with a human rights NGO called Spravedlivost (Justice), which is against Kremlin's policies.

There is also another reason for keeping hope for the future of civil society in Russia and Iran. Ljubownikow et al. (2013) argue that the development of civil society in Russia could be distinct from the western experience, due to cultural differences and historical legacies. Civil engagement is still possible within the institutionalization of cooperation between NGOs and the state, which is completely at odds with the western understanding of civil society. The same argument could be proposed for civil society in Iran. Scholars have used alternative terms such as 'informal' activism (Bayat 1997), 'nascent civil society' (Weigle 2000), 'movement society' (Uhline 2006), and 'virtual civil society' (Cross 2010; Beissinger 2017) to describe how civil activism in countries like Russia and Iran is following a different path from what western countries have already experienced. These new forms of civil activism have considerable weaknesses, but they can genuinely challenge the established power. Further study is needed to know more about the functions of the new forms of civil society in developing countries such as Russia and Iran.

\section{Bibliography}

Abrahamian, E. (2018). A history of modern Iran (2nd ed.).

Cambridge University Press.

https://doi.org/10.1017/9781108182348 
Accounts Chamber of the Russian Federation. (2019). Schetnaja palata Rossijskoj Federacii (2019) Analiticheskij otchet o hode ispolnenija federal'nogo bjudzheta i bjudzhetov gosudarstvennyh vnebjudzhetnyh fondov Rossijskoj Federacii za janvar' - dekabr' 2018 goda" [Analytical report on the implementation of the federal budget and the budgets of state extra-budgetary funds of the Russian Federation for January]. Accounts Chamber of the Russian Federation. https://ach.gov.ru/promo/analytical-report-federal-budget2018/report.html

Arato, A. (1991). Social movements and civil society in the Soviet Union. In J. Sedaitis \& J. Butterfield (Eds.), Perestroika from below: Social movements and civil society in the Soviet Union (pp. 197-214). Westview Press.

Aslaksen, S. (2010). Oil and democracy: More than a cross-country correlation? Journal of Peace Research, 47(4), 421-431. https://doi.org/10.1177/0022343310368348

Auty, R. M. (2001). The political economy of resource-driven growth. European Economic Review, 45(4-6), 839-846. https://doi.org/10.1016/S0014-2921(01)00126-X

Auty, R. M. (2010). Elites, rent-cycling and development: Adjustment to land scarcity in Mauritius, Kenya and Côte d'Ivoire.

Development Policy Review, 28(4), 411-433. https://doi.org/10.1111/j.1467-7679.2010.00490.x

Aytaç, S. E., Mousseau, M., \& Örsün, Ö. F. (2016). Why some countries are immune from the resource curse: The role of economic norms. Democratization, 23(1), 71-92. https://doi.org/10.1080/13510347.2014.964216

Azad, Shirzad. (2010). The politics of privatization in Iran. Middle East Review of International Affairs (Online), 14(4), 60-71. Arezki, R., \& Brückner, M. (2011). Oil rents, corruption, and state stability: Evidence from panel data regressions. European Economic Review, 55(7), 955-963. https://doi.org/10.1016/i.euroecorev.2011.03.004

Arezki, R., Nabli, M. K., \& IMF Institute. (2012). Natural resources, volatility, and inclusive growth: Perspectives from the Middle 
East and north Africa. International Monetary Fund. http://site.ebrary.com/id/10566334

Arezki, R., \& Gylfason, T. (2013). Resource rents, democracy, corruption and conflict: Evidence from Sub-Saharan Africa. Journal of African Economies, 22(4), 552-569. https://doi.org/10.1093/jae/ejs036

Badeeb, R. A., Lean, H. H., \& Clark, J. (2017). The evolution of the natural resource curse thesis: A critical literature survey. Resources Policy, 51, 123-134. https://doi.org/10.1016/j.resourpol.2016.10.015

Bayat, Asef. (1997). Un-civil society: The politics of the 'informal people.' Third World Quarterly, 18(1), 53-72.

BBC (British Broadcasting Corporation). (2015, November 9). Russia censures memorial rights group as "Foreign Agent." BBC (British Broadcasting Corporation). https://www.bbc.com/news/world-europe-34767014

BBC (British Broadcasting Corporation). (2019, April 26). Russia profile - Timeline. BBC (British Broadcasting Corporation). https://www.bbc.com/news/world-europe-17840446

Beissinger, M. R. (2017). "Conventional" and "Virtual" Civil Societies in Autocratic Regimes. Comparative Politics, 49(3), 351-371. https://doi.org/10.5129/001041517820934267

Bernhard, M., Tzelgov, E., Jung, D.-J., Coppedge, M., \& Lindberg, S. I. (2015). The Varieties of Democracy Core Civil Society Index. SSRN Electronic Journal. https://doi.org/10.2139/ssrn.2667493 Blasi, J. R., Kroumova, M., Kruse, D., \& Shleifer, A. (2018). Kremlin capitalism: Privatizing the Russian economy. https://www.degruyter.com/doi/book/10.7591/9781501722226 Brown, L. C., \& Buchta, W. (2000). Who rules Iran? The structure of power in the Islamic Republic. Foreign Affairs, 79(6), 188. https://doi.org/10.2307/20050019

Chebankova, E. (2012). State-sponsored civic associations in Russia: Systemic integration or the 'war of position'? East European Politics, 28(4), 390-408. https://doi.org/10.1080/21599165.2012.674939 
Cross, Kevin. (2010). Why Iran's green movement faltered: The limits of information technology in a rentier state. SAIS Review of International Affairs, 30(2), 169-187.

Dehghan, Saeed K. (2016, November 4). Silencing of journalist draws huge backlash from Iranian public. The Guardian. https://www.theguardian.com/world/iranblog/2016/nov/04/silencing-iranian-journalist-draws-hugepublic-backlash-tehran-corruption

Desai, R. M., Freinkman, L., \& Goldberg, I. (2005). Fiscal federalism in rentier regions: Evidence from Russia. Journal of Comparative Economics, 33(4), 814-834. https://doi.org/10.1016/j.jce.2005.08.004

Dunning, T. (2008). Crude democracy: Natural resource wealth and political regimes. Cambridge Univ. Press. http://www.myilibrary.com?id=194476

DW Persian (Deutsche Welle Persian). (2021, February 2). Saba Azarpeik, rooznam-eh negar-e fessad yab bazdasht shod. [Saba Azarpeik, the corruption-detector journalist arrested.]. DW Persian (Deutsche Welle Persian). https://p.dw.com/p/3p2bJ

EIU (Economist Intelligence Unit). (2020, January 22). Global democracy has another bad year. EIU (Economist Intelligence Unit). https://www.economist.com/graphicdetail/2020/01/22/global-democracy-has-another-bad-year

Encyclopedia Britannica. (n.d.). Russia: Government and society. In Encyclopedia Britannica. Retrieved September 20, 2020 from https://www.britannica.com/place/Russia/Government-andsociety

Evans, Alfred B. (2006). Civil society in the Soviet Union? In A. B. Evans, L. A. Henry, \& L. M. Sundstrom (Eds.), Russian civil society: A critical assessment (pp. 28-54). M.E. Sharpe.

Fars (Fars News Agency). (2019, August 4). Shekayat-e "Dideh-bane Shafafiat va Edalat" az raeiss-e Sazman-e Khossousi-sazi [Transparency and Justice Watch sues head of the Privatization Organization]. Fars (Fars News Agency). https://www.farsnews.ir/news/13980513000698/ 
GAN (GAN Integrity). (2020, August). Iran corruption report. GAN Business Anti-Corruption Portal.

https://www.ganintegrity.com/portal/country-profiles/iran/

Gheissari, A., \& Nasr, V. (2009). Democracy in Iran: History and the quest for liberty. Oxford University Press.

Gibelman, M., \& Gelman, S. R. (2004). A loss of credibility: Patterns of wrongdoing among nongovernmental organizations.

VOLUNTAS: International Journal of Voluntary and Nonprofit Organizations, 15(4), 355-381. https://doi.org/10.1007/s11266004-1237-7

Gnezdilova, O. (2009, April 30). Russia's NGOs: Strangled by red tape. Open Democracy.

https://www.opendemocracy.net/en/russias-ngos-strangled-byred-tape/

Greenlee, J., Fischer, M., Gordon, T., \& Keating, E. (2007). An investigation of fraud in nonprofit organizations: Occurrences and deterrents. Nonprofit and Voluntary Sector Quarterly, 36(4), 676-694. https://doi.org/10.1177/0899764007300407

Grimes, M. (2013). The contingencies of societal accountability:

Examining the link between civil society and good government. Studies in Comparative International Development, 48(4), 380402. https://doi.org/10.1007/s12116-012-9126-3

Gulf Oil \& Gas. (n.d.). Oil \& gas companies in Russia. Gulf Oil \& Gas. Retrieved October 12, 2020, from https://www.gulfoilandgas.com/webpro1/prod1/suplista.asp?id= 327\&yx1=RU

Gylfason, T., \& Zoega, G. (2006). Natural resources and economic growth: The role of investment. The World Economy, 29(8), 1091-1115. https://doi.org/10.1111/j.1467-9701.2006.00807.x

Haj Yousefi, A. M. (1998). Esteghlal-e nesbi-ye dowlat ya jame'ey-e madani dar Jomhouri-ye Eslami-ye Iran [The relative independence of the state or civil society in I.R.I]. Faslname-Ye Motaleat-e Rahbordi [Strategic Studies Quarterly], 1(2), 69-94. Hanson, P. (2007). The Russian economic puzzle: Going forwards, backwards or sideways? International Affairs, 83(5), 869-889. https://doi.org/10.1111/j.1468-2346.2007.00660.x 
Henderson, S. L. (2011). Civil society in Russia: State-society relations in the post-Yeltsin era. Problems of PostCommunism, 58(3), 11-27. https://doi.org/10.2753/PPC10758216580302

Herb, M. (2005). No representation without taxation? Rents, development, and democracy. Comparative Politics, 37(3), 297-316. https://doi.org/10.2307/20072891

Hertzfeld, J. M. (1991). Joint ventures: Saving the Soviets from perestroika. Harvard Business Review, 69(1), 80-91.

Hines, J. H., Josefson, J. A., Strizh, V., \& Marchenko, A. V. (2020, July 13). Russia adopts major amendments to its constitution. Lexology.

https://www.lexology.com/library/detail.aspx?g=9173f461a6e0-4b5d-9964-c2632abc2fc6

Holmes, L. (2012). Corruption in post-Soviet Russia. Global Change, Peace \& Security, 24(2), 235-250. https://doi.org/10.1080/14781158.2012.678991

JFJ (Justice for Journalists Foundation). (2019). Attacks against journalists and media workers in Russia. Justice for Journalists Foundation. JFJ (Justice for Journalists Foundation). https://jfi.fund/wp-content/uploads/2019/10/FINAL-ENGRUSSIA-REPORT-1.pdf

Johnston, M. (1998). Fighting systemic corruption: Social foundations for institutional reform. The European Journal of Development Research, 10(1), 85-104. https://doi.org/10.1080/09578819808426703

Kalb, Z. (2019). Corporatist coalitions as agents of civil society: The politics of student and labour unions in Iran. Mediterranean Politics, 24(4), 467-490.

https://doi.org/10.1080/13629395.2019.1639021

Kaldor, M. (2003). Civil society and accountability. Journal of Human Development, 4(1), 5-27. https://doi.org/10.1080/1464988032000051469

Karl, T. L. (2004). Oil-led development: Social, political, and economic consequences. In Encyclopedia of Energy (pp. 661672). Elsevier. https://doi.org/10.1016/B0-12-176480-X/00550$\underline{7}$ 
Karl, T. L. (2005). Understanding the resource curse. In Tsalik, S., Schiffrin, A. (Eds.), Covering oil: A reporter's guide to energy and development (pp. 21-27). Open Society Institute, New York.

Khodorkovsky. (2018, August 3). Who guards the guardians? The illusion of civil society in Russia. Khodorkovsky. https://khodorkovsky.com/guards-guardians-illusion-civilsociety-russia/

Kolesnikov, A. (2019 a). Russia's three fronts of civil society. Carnegie Moscow Center. https://carnegie.ru/2019/06/19/russia-s-three-fronts-of-civilsociety-pub-79348

Kolesnikov, A. (2019 b). The split in Russia's civil society. Carnegie Moscow Center. https://carnegie.ru/commentary/79012

Laruelle, M. (2020, June 25). Russia's constitutional amendments keep several futures open for Putin. Russia Matters. https://www.russiamatters.org/analysis/russias-constitutionalamendments-keep-several-futures-open-putin

Levin, M., \& Satarov, G. (2000). Corruption and institutions in Russia. European Journal of Political Economy, 16(1), 113-132. https://doi.org/10.1016/S0176-2680(99)00050-6

Levitsky, S., \& Way, L. (2002). Elections without Democracy: The rise of competitive authoritarianism. Journal of Democracy, 13(2), 51-65. https://doi.org/10.1353/jod.2002.0026

Levitsky, S., \& Way, L. A. (2010). Competitive authoritarianism: Hybrid regimes after the Cold War. Cambridge University Press.

Lipin, M., \& Haghjoo, R. (2021, February 13). Iran journalist gets 2 years in prison for writing about Vice President's brother's corruption case. VOA (Voice of America).

https://www.voanews.com/middle-east/voa-news-iran/iranjournalist-gets-2-years-prison-writing-about-vice-presidents

Ljubownikow, S., Crotty, J., \& Rodgers, P. W. (2013). The state and civil society in Post-Soviet Russia: The development of a Russian-style civil society. Progress in Development Studies, 13(2), 153-166. https://doi.org/10.1177/1464993412466507 
Locatelli, C. (2006). The Russian oil industry between public and private governance: Obstacles to international oil companies' investment strategies. Energy Policy, 34(9), 1075-1085. https://doi.org/10.1016/i.enpol.2004.09.007

Mungiu-Pippidi, A. (2013). Controlling corruption through collective action. Journal of Democracy, 24(1), 101-115. https://doi.org/10.1353/jod.2013.0020

OEC (Observatory of Economic Complexity). (n.d. a). Country profile: Russia. OEC (Observatory of Economic Complexity). Retrieved November 16, 2020, from https://oec.world/en/profile/country/rus/

OEC (Observatory of Economic Complexity). (n.d. b). Country profile: Iran. OEC (Observatory of Economic Complexity). Retrieved November 16, 2020, from https://oec.world/en/profile/country/irn/

Olimpieva, I. (2009). Informal intermediaries and civic organizations in state-business relationships in Russia. In V. Pérez-Díaz (Ed.), Markets and Civil Society: The European Experience in Comparative Perspective (pp. 202-221). Berghahn Books.

Okada, K., \& Samreth, S. (2017). Corruption and natural resource rents: Evidence from quantile regression. Applied Economics Letters, 24(20), 1490-1493. https://doi.org/10.1080/13504851.2017.1287849

Remington, T. F. (2009). Parliament and the dominant party regime. In S. K. Wegren \& D. R. Herspring (Eds.), After Putin's Russia: Past imperfect, future uncertain. Rowman \& Littlefield Publishers.

Rivetti, P. (2012). Co-opting civil activism in Iran. In P. Aarts \& F. Cavatorta (Eds.), Civil society in Syria and Iran: Activism in authoritarian contexts (pp. 279-302). Lynne Rienner.

Romanov, P., \& larskaia-Smirnova, E. (2015). 'Foreign agents' in the field of social policy research: The demise of civil liberties and academic freedom in contemporary Russia. Journal of European Social Policy, 25(4), 359-365. https://doi.org/10.1177/0958928715594539

Ross, M. L. (2013). The oil curse: How petroleum wealth shapes the development of nations. Princeton University Press. 
Sachs, J. D. (1992). Privatization in Russia: Some lessons from Eastern Europe. The American Economic Review, 82(2), 4348. https://www.jstor.org/stable/2117373

Sadeghi, H., Arani, A. A., \& Shahri, V. S. (2011). Andazeh giri-ye fessed-e mali dar Iran ba estefadeh az mantegh-e fazi (rouykard-e eghtesadi) [Measuring financial corruption in Iran using fuzzy logic (economic approach)]. Pajouheshname-ye Eghtesadi [Economic Research], 10(39), 174-139.

Sazandegi (Daily Newspaper). (2019, September 23). Eghtesad-e Iran dast-e kist? [Whose Hand is Iran's Economy in?]. Sazandegi (Daily Newspaper). http://sazandeginews.com/News/5374

Shashkova, A., Verlaine, M., \& Kudryashova, E. (2020). On modifications to the constitution of the Russian Federation in 2020. Russian Law Journal, 8(1), 60-83. https://doi.org/10.17589/2309-8678-2020-8-1-60-83

Shelley, L. (2005). Civil society mobilized against corruption: Russia and Ukraine. In M. Johnston (Ed.), Civil society and corruption: Mobilizing for reform (pp. 3-21). University Press of America.

Shim, D. C., \& Eom, T. H. (2009). Anticorruption effects of information communication and technology (ICT) and social capital. International Review of Administrative Sciences, 75(1), 99-116. https://doi.org/10.1177/0020852308099508

Squier, J. (2002). Civil society and the challenge of Russian gosudarstvennost. Demokratizatsiya, 10(2), 166-182.

Stephenson, S. (2017). It takes two to tango: The state and organized crime in Russia. Current Sociology, 65(3), 411-426. https://doi.org/10.1177/0011392116681384

Stewart, S., \& Dollbaum, J. M. (2017). Civil society development in Russia and Ukraine: Diverging paths. Communist and PostCommunist Studies, 50(3), 207-220.

https://doi.org/10.1016/j.postcomstud.2017.08.001

Sullivan, J. D. (2006). Corruption, economic development, and governance: Private sector perspectives from developing countries. Private Sector Opinion, 2. World Bank. https://openknowledge.worldbank.org/handle/10986/11199 
Transparency International. (n.d. a). Corruption Perception Index.

Transparency International. Retrieved February 10, 2021, from https://www.transparency.org/en/cpi/

Transparency International. (n.d. b). Technical Methodology Note.

Corruption Perception Index. Transparency International.

Retrieved May 16, 2021, from

https://www.transparency.org/en/cpi/

TJW (Transparency and Justice Watch). (n.d.). Assassnameh [Articles of Association]. TJW (Transparency and Justice Watch). Retrieved January 9, 2020, from http://daad.ir/2015/10/24/

TJW (Transparency and Justice Watch). (2020, August 16). Ahmad Tavakkoli: Shaffafiat az daftar-e rahbari ra peygiri khaham kard. Nazar-e Ishan mosbat ast [Ahmad Tavakoli: I will follow up the transparency of the Supreme Leader's Office. His opinion is positive]. TJW (Transparency and Justice Watch). http://daad.ir/2020/08/16/

TJW (Transparency and Justice Watch). (2019, January 15). Tavakkoli: Dideh Ban-e Shaffafiat va Edalat az moaven-e raees-e jomhouri shekayat mikonad. [Tavakoli: TJW sues the Vice President]. TJW (Transparency and Justice Watch). http://daad.ir/2019/01/15/

TJW (Transparency and Justice Watch). (2018, December 1). Dideh Baan-e Shaffafiat va Edalat az shekayat-e Bank-e Markazi tabrae shod [Transparency and Justice Watch was acquitted from the lawsuit filed by the Central Bank]. TJW (Transparency and Justice Watch). http://daad.ir/2018/12/01/

Tompson, W. (2005). The political implications of Russia's resourcebased economy. Post-Soviet Affairs, 21(4), 335-359. https://doi.org/10.1080/1060586X.2005.12049785

Tusalem, R. F. (2007). A boon or a bane? The role of civil society in third- and fourth-wave democracies. International Political Science Review, 28(3), 361-386. https://doi.org/10.1177/0192512107077097

Uhlin, A. (2006). Post-Soviet civil society: Democratization in Russia and the Baltic States. Routledge. 
Upadhyay, A. (2006, November 11-17). Civil society and democratic space in Russia. Economic and Political Weekly, 41(45), 46514653.

V-Dem (Varieties of Democracy). (n.d.). Variable graphs: Iran and Russia. V-Dem (Varieties of Democracy). Retrieved December 15, 2020, from https://www.vdem.net/en/analysis/VariableGraph/

Volunteer Activities. (2018). Civil society in Iran and its future prospects: A case study. Volunteer Activities Institute. https://volunteeractivists.nl/en/civil-society-in-iran/

Villanueva, P. A. G. (2020). Why civil society cannot battle it all alone: The roles of civil society environment, transparent laws and quality of public administration in political corruption mitigation. International Journal of Public Administration, 43(6), 552-561. https://doi.org/10.1080/01900692.2019.1638933

Volkov, V. (2016). Violent entrepreneurs: The use of force in the making of Russian capitalism. Cornell University Press.

World Bank. (n.d.). Oil rents (\% GDP)—Iran, Islamic Rep. Vs. Russian Federation. World Bank. Retrieved December 15, 2020, from https://data.worldbank.org/indicator/NY.GDP.PETR.RT.ZS?end $=2017 \&$ locations $=I R-R U \&$ start=1988\&type=points\&view=chart

Weigle, M. A. (2010). Russia's liberal project: State-society relations in the transition from communism. The Pennsylvania State University Press. 